\section{Japanese eye human genome}

\section{Tokyo}

INTEREST in sequencing the human genome is taking off in Japan. Two international meetings have been held in the past week to discuss the issue, and the Science and Technology Agency (STA) will apply for funds to try and get the project off the ground next year.

For several years, Professor Akiyoshi Wada of Tokyo University has led a government-industry project funded by the agency to develop automated equipment for reading long DNA sequences, such as the human genome. Last week, he chaired an international workshop at Okayama, sponsored by the Hayashibara Foundation. The workshop was followed up by a one-day symposium in Tokyo on "a strategy for mapping and sequencing of the human genome" attended by several of the workshop speakers and sponsored by the STA and several Japanese companies.

An impressive array of technology was lined up by the Japanese, including a robot system developed by Seiko Instruments for DNA-sequencing based on the Sanger method, Fuji Photo Film's continuous process for manufacturing ultrathin $(0.2 \mathrm{~mm})$ sheets of precast gels and a laser system developed by Hitachi for reading DNA sequences on gels marked using fluorescence. Fuji Film are already marketing their gel sheets in Japan and the only major complaint from customers, says Tsutomu Hamaoka of Fuji, is the price (Y2,500, about $£ 17$ per sheet).

But the rest of thew world has not been left behind. After the Hitachi speaker had finished, Lennart Philipson of the European Molecular Biology Laboratory (EMBL) pointed out that EMBL has already patented a similar laser-based system to that of Hitachi and it will be marketed shortly.

Despite such competition, many of the speakers called for international collaboration. And, although differences of opinion exist over how and when the human genome project should start, there was general agreement that the project should be a joint effort by the United States, Japan and Europe.

The STA will apply next month for a few hundred million yen (a few million dollars) to put together a fully automated sequencing system using machines developed by Seiko, Fuji and Hitachi and to develop techniques for handling and dissecting chromosomes. Further discussions will also be held with the US Department of Energy on the possibility of USJapan collaboration. But to mount a truly international project will require much more funding.

David Swinbanks

\title{
Titanium content brings Vinland map back into play
}

\section{London}

THE Vinland map, which came to light in the early $1960 \mathrm{~s}$, and was believed for some years to be the earliest cartographic evidence of the existence of North America, was pronounced a forgery in 1974, when analysis of microparticles removed from its surface led McCrone Associates of Chicago to conclude that the ink used was based on titanium oxide, and hence of twentieth century origin. But now work by a team at the Crocker Nuclear Laboratory of the University of Califonia (published in a recent issue of Analytical Chemistry) has called into question the McCrone results, and once more opens up the question of the map's authenticity.

Using a proton milliprobe, collimated to $1.0 \mathrm{~mm} \times 0.5 \mathrm{~mm}$ (because the width of the lines on the map is of the order of 0.5 $\mathrm{mm}$ ), Cahill and his team carried out 159 analyses of the parchment and ink of the map. According to the McCrone report, the alleged forger had used a titaniumbased pigment to simulate the stain left by fifteenth century inks that have had their black layer flaked away by time. But according to the Cahill team, about onethird of all such lines on the map showed no titanium whatsoever above the minimum detectable level of $0.2 \mathrm{ng} \mathrm{cm}^{-2}$.

Cahill stresses that the McCrone conclusions are based on the $\mathrm{X}$-ray diffraction pattern and four electron diffraction patterns plus qualititative observations of optical behaviour. His own team, on the other hand, not only made a considerably more extensive study of the map but also

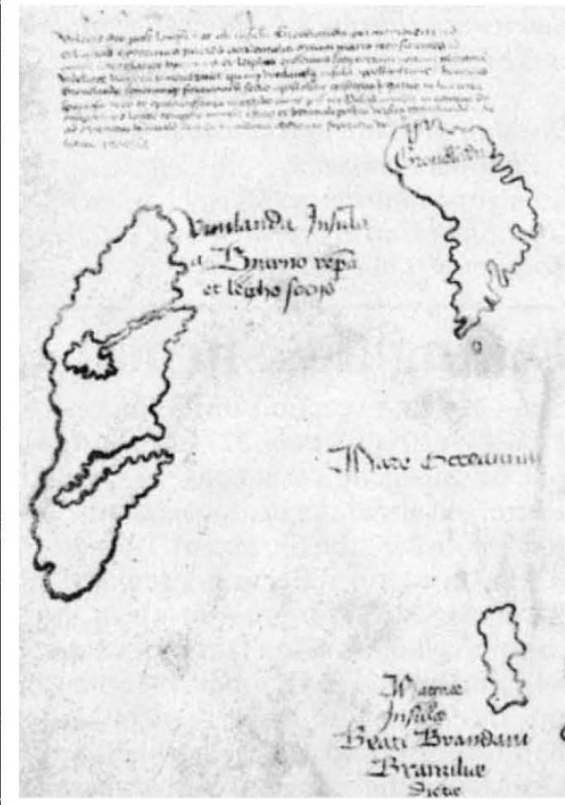

of undoubtedly authentic fifteenth and sixteenth century manuscripts, and specimens prepared using modern ink applied to a seventeenth century parchment of similar elemental composition to that of the map.

Although, in effect, refuting the McCrone report, Cahill and his team stress that they do not claim that the map is therefore authentic. Further research is needed, they say, although the obvious test, carbon-14, might be inconclusive, as it would give a dating for the parchment, not the drawing.

What is needed, too, is further cartographic and historical research on the content of the map - a sensitive subject, incidentally, in the United States, where citizens of Italian descent feel that the evidence of the Icelandic sagas for a land-fall in "Vinland" (North America) somehow detracts from Columbus's achievement. The real problem of the map for many Scandinavian scholars is Greenland, which seems simply "too good". The Viking settlers established only two small colonies in the south but the map gives, in effect, only a slightly distorted version of the true outline of Greenland, which if not a very lucky guess would seem to call for circumnavigation and sophisticated highlatitude survey instruments. Furthermore, the consensus of Scandinavian geographers of the alleged period of the map, and indeed considerably later, was that Greenland was not an island but part of the European landmass, curving eastwards until it linked up with northern Russia.

Vera Rich

Part of the Vinland map, showing North America (left), presumably as deduced from the Viking sagas. Greenland is mapped too well for the taste of Scandinavian scholars. 